\title{
Légzőszervi megbetegedések primer immundefektusokban
}

\author{
Nyul Zoltán dr. \\ Pécsi Tudományegyetem, Általános Orvostudományi Kar, Klinikai Központ, Gyermekgyógyászati Klinika, Pécs
}

\begin{abstract}
Veleszületett immundefektusokban a légutak fertőzései a leggyakoribb prezentációs jelek és egyben a vezető halálok. Az egyes immundefektusokra jellemző lehet a domináns kórokozó vagy kórokozóspektrum, amelynek ismerete a fertőzések empirikus kezelésében és prevenciójában játszik döntő szerepet, vagy éppen fordítva, a szokványostól eltérő patogén azonosítása terelheti gyanúnkat immundefektus irányába. Az akut légúti betegségek mellett a primer immundefektus krónikus tüdőbetegségekre is gyakran hajlamosít. A visszatérő fertőzések következtében az alsó légutak visszafordíthatatlan szerkezeti károsodása, bronchiectasia alakulhat ki, amely további fertőzések kiindulási gócaként szolgálhat. A krónikus tüdőbetegségek másik csoportja, az interstitialis tüdőbetegségek az infekcióktól függetlenek, és az egyes immundefektusokban jellemző immunregulációs zavar megnyilvánulásaként foghatók fel. Az életminőség, a hosszú távú prognózis tekintetében döntő jelentőségű a másodlagos tüdőkárosodás szempontjából rizikócsoportot jelentő betegek azonosítása és a rendszeres szúrővizsgálatok elvégzése az elváltozások korai felismerése érdekében.
\end{abstract}

Orv Hetil. 2018; 159(49): 2043-2049.

Kulcsszavak: primer immundefektus, légzőrendszeri fertőzések, bronchiectasia, interstitialis tüdőbetegség

\section{Respiratory manifestations in primary immunodeficiencies}

The respiratory infections are the most common presentations and leading cause of morbidity and mortality in primary immunodeficiencies. The pathogen or spectrum of pathogens may be characteristic for the underlying primary immunodeficiency, and that knowledge plays an important role in the empirical treatment or prevention of the infections, or, conversely, the identification of an unusual pathogen may raise the suspicion on an immunodeficiency. Apart from the acute respiratory infections, chronic lung diseases are also common complications. The recurrent infections result in bronchiectasis, an irreversible structural damage of the respiratory tract, that frequently serve as locus for subsequent infections. The other group of chronic pulmonary complications are the interstitial lung diseases, which seem to be independent from infections and can be regarded as the pulmonary manifestation of the immune dysregulation. It is important to identify those patients with immunodeficiency who are at increased risk of secondary lung complications and to regularly screen this group for the early detection of the pulmonary complications.

Keywords: primary immunodeficiency, respiratory infections, bronchiectasis, interstitial lung disease

Nyul Z. [Respiratory manifestations in primary immunodeficiencies]. Orv Hetil. 2018; 159(49): 2043-2049

(Beérkezett: 2018. augusztus 6.; elfogadva: 2018. szeptember 7.)

\section{Rövidítések}

$\mathrm{BAL}=$ (bronchoalveolaris lavage) bronchoalveolaris mosás; $\mathrm{BCR}=(\mathrm{B}$-cell receptor $)$ B-sejt-receptor; BTK $=($ Bruton's tyrosine kinase) Bruton-féle tirozin-kináz; CD40L = CD40-ligand; $\mathrm{CGD}=($ chronic granulomatous disease $)$ krónikus granulomatosus betegség; CID = (combined immunodeficiency) kombinált immunhiányos állapot; $\mathrm{CO}=$ szén-monoxid; CSF2RA $=($ GM-CSF 2 receptor alpha subunit $)$ GMCSF2-re- ceptor-alfa-alegység; CTLA4 $=$ (citotoxic T-lymphocyte antigen 4$)$ citotoxicus T-lymphocytaantigén- 4 ; CVID $=($ common variable immunodeficiency) variábilis immunhiány; ESID = (European Society for Immunodeficiencies) Európai Immundeficientia Társaság; $\mathrm{FEV}_{1}=$ (forced vital capacity in 1 second $)$ erőltetett kilégzési térfogat $1 \mathrm{~s}$ alatt; FVC = erőltetett vitálkapacitás; GLILD = (granulomatous-lymphocytic interstitial lung disease) granulomatosus-lymphocytás interstitialis tüdő- 
betegség; GM-CSF = (granulocyte-macrophage colony-stimulating factor) granulocyta-macrophag kolónia stimuláló faktor; HIES = hiper-IgE-szindróma; HIGM = hiper-IgM-szindróma; HRCT $=$ (high-resolution computer tomography) nagy felbontású komputertomográfia; ILD = (interstitial lung disease) interstitialis tüdőbetegség; LRBA = (lipopolysaccharide-responsive beige-like anchor) lipopoliszacharidra reagáló bézsszerü horgony; NADPH = (nicotinamide adenine dinucleotide phosphate) nikotinamid-adenin-dinukleotid-foszfát; PAD = (primary antibody deficiency) primer antitesthiányos állapot; PI3KD = (phosphoinositide 3-kinase delta) foszfoinozitid3-kináz-delta; PID = (primary immunodeficiency) primer immundeficientia; $\mathrm{RAG}=$ (recombination-activating gene $)$ rekombinációaktiváló gén; RSV = (respiratory syncytial virus) respiratoricus syncytialis vírus; $\mathrm{sCID}=($ severe combined $\mathrm{im}-$ munodeficiency) súlyos kombinált immunhiányos állapot; STAT3 $=($ signal transducer and activator of transcription 3$)$ jelátvivő és transzkripciós aktivátor-3; STAT5b $=$ (signal transducer and activator of transcription $5 \mathrm{~b}$ ) jelátvivő és transzkripciós aktivátor-5b; XIAP $=(\mathrm{X}$-linked inhibitor of apoptosis $)$ $\mathrm{X}$-hez kötött apoptózisgátló; XLA = (X-linked agammaglobulinemia) X-hez kötött agammaglobulinaemia

A jelenleg ismert több mint 350 veleszületett primer immundeficientia (PID) [1] döntő többségében a fertőzésekre való fokozott hajlam áll az előtérben. A légzőrendszer fertőzései a vezető morbiditási és mortalitási tényezők. A jelen közleményben a PID-ben előforduló légúti, elsôsorban alsó légúti betegségeket és ezek diagnosztikus aspektusait tekintjük át. A légúti szövődmények didaktikailag infekciós eredetú akut és krónikus légúti betegségekre, valamint nem infekciós obstruktív és restriktív tüdőbetegségekre oszthatók fel [2].

\section{Infekciós eredetư légzőszervi betegségek PID-ben}

A primer antitestdefektusok (PAD) képezik a primer immundefektusok legnagyobb csoportját. A légutakban a különböző immunglobulinizotípusoknak eltérő a lokalizációja és a funkciója. A felső és alsó légutakban a nyálkahártya-asszociált lymphoid szövet által termelt secretoros IgA (sIgA) és IgM fordul eló; az elóbbi a bakteriális adhaesiogátlásban és toxinsemlegesítésben, míg az utóbbi a komplementaktivációban, valamint a kórokozók, különösen a vírusok agglutinatiójában hatékony. Alveolaris szinten a keringésből származó IgG dominál, és a bacterialis fertózések megelózésében van kiemelt szerepe [3]. A leggyakrabban előforduló PAD-kórképek közül a szelektív IgA-hiány az esetek felében tünetmentes, az IgG-alosztály-hiány vagy a specifikus antitestdefektusok klinikailag az enyhébb defektusok közé tartoznak. A klinikai következmények miatt nagyobb jelentőséggel bírnak az egyidejúleg több vagy az összes immunglobulinizotípus csökkenését vagy hiányát okozó számbeli vagy funkcionális B-sejt-zavarok, az agammaglobulinaemiák és a variábilis immundeficientia (CVID). Az agammaglo- bulinaemiák 85\%-a X-hez kötött (XLA), és a B-sejt-receptor (BCR) jelátviteléért felelős BTK-gén mutációja okozza [4]. Ennek következtében a B-sejt-érés a pro-Blymphocyta-stádium után megreked, a periférián nincs vagy csak kisszámú $\mathrm{B}$-sejt található, minden izotípust érintő súlyos immunglobulinhiánnyal. A leggyakoribb szimptómás PID-ként a CVID klinikailag és genetikailag heterogén csoportot képez. A sinopulmonalis fertőzésekre való hajlam mellett jellemző a különböző autoimmun és malignus lymphoproliferativ betegségek előfordulása. Génmutáció a betegek kisebb hányadában ismert és igazolható. A kórkép hátterében T-B lymphocyta interakció zavar feltételezhető, melynek következtében gátolt a B-sejtek plazmasejtté, illetve osztályváltott memóriasejtekké történő differenciálódása. Immunológiailag IgG- és IgA-, esetenként IgM-hypogammaglobulinaemia, valamint csökkent antitestválasz jellemzi $[5,6]$. Egy vizsgálat szerint a CVID-betegek 76\%-ában mérhetetlenül alacsony az IgE [7].

$\mathrm{Az}$ antitesthiány leggyakoribb következménye a felső és alsó légutak visszatérő, elhúzódó fertőzései, melyek klinikailag rhinosinusitis, otitis media, bronchitis, pneumonia és később bronchiectasia képében nyilvánulnak meg. Az infekciók jellemzően az anyai antitestek eltúnésével, 6 hónapos kor után kezdődnek. A rekurráló légúti fertőzések minden életkori kategóriában markáns gyanújelnek számítanak. A Jeffrey Modell Alapítvány által kidolgozott 10, PID-re figyelmeztető jel (1. táblázat) közül három - a recidív otitis, sinusitis és pneumonia - a

1. táblázat |A primer immundefektus 10 figyelmeztető jele [8]

\begin{tabular}{ll}
\hline Gyermekek & Felnőttek \\
\hline $\begin{array}{l}\text { 4 vagy több otitis egy év alatt } \\
2 \text { vagy több súlyos sinusitis egy }\end{array}$ & $\begin{array}{l}2 \text { vagy több otitis egy év alatt } \\
\text { alatt, allergia hiányában }\end{array}$ \\
\hline $\begin{array}{l}\text { év alatt } \\
2 \text { vagy több tüdógyulladás egy év } \\
\text { alatt }\end{array}$ & $\begin{array}{l}1 \text { tüdőgyulladás évente, több } \\
\text { mint egy évig }\end{array}$ \\
\hline $\begin{array}{l}2 \text { vagy több hónapig tartó antibi- } \\
\text { otikus kezelés csekély eredmény- } \\
\text { nyel }\end{array}$ & Krónikus hasmenés súlyvesztéssel \\
\hline
\end{tabular}

Csecsemőkori súly- és hosszfejlő- Visszatérő vírusfertőzések désbeli megtorpanás

\begin{tabular}{ll}
\hline $\begin{array}{l}\text { Visszatérő bőr- vagy szervi } \\
\text { tályogok }\end{array}$ & $\begin{array}{l}\text { Intravénás antibiotikum adásának } \\
\text { szükségessége a fertőzések } \\
\text { kezeléséhez }\end{array}$ \\
\hline $\begin{array}{l}\text { Perzisztáló gombás száj- vagy } \\
\text { bőrfertőzés }\end{array}$ & $\begin{array}{l}\text { A bőr vagy belső szervek mély, } \\
\text { visszatérő tályogjai }\end{array}$ \\
\hline $\begin{array}{l}\text { Intravénás antibiotikum adásának } \\
\text { szükségessége a fertőzések } \\
\text { kezeléséhez }\end{array}$ & $\begin{array}{l}\text { Perzisztáló gombás száj- vagy } \\
\text { bőrfertőzés }\end{array}$ \\
\hline $\begin{array}{l}2 \text { vagy több invazív fertőzés } \\
\text { szepszis, osteomyelitis, } \\
\text { meningitis) }\end{array}$ & $\begin{array}{l}\text { Egyébként ártalmatlan TBC-sze- } \\
\text { rű fertőzés }\end{array}$ \\
\hline Pozitív családi kórelőzmény & Pozitív családi kórelőzmény \\
\hline
\end{tabular}

TBC = tuberkulózis 


\begin{tabular}{|c|c|c|c|}
\hline Antitestdefektusok (PAD) & Kombinált immundefektusok & Phagocytadefektusok & A komplementrendszer defektusai \\
\hline $\begin{array}{l}\text { Streptococcus pneumoniae, } \\
\text { Haemophilus influenzae, } \\
\text { Staphylococcus aureus, Moraxella } \\
\text { catarrhalis, Bordetella pertussis, } \\
\text { Pseudomonas aeruginosa }\end{array}$ & $\begin{array}{l}\text { (Mint antitestdefektusok plusz) } \\
\text { Listeria monocytogenes, } \\
\text { Pneumocystis jirovecii }\end{array}$ & $\begin{array}{l}\text { Staphylococcus aureus, } \\
\text { Pseudomonas, } \\
\text { Serratia, Burkholderia, Klebsiella, } \\
\text { Nocardia }\end{array}$ & $\begin{array}{l}\text { Streptococcus pneumoniae, } \\
\text { Haemophilus influenzae, } \\
\text { Neisseria meningitidis }\end{array}$ \\
\hline \multirow[t]{3}{*}{$\begin{array}{l}\text { Rhinovirus, coronavírusok, } \\
\text { adenovírus }\end{array}$} & $\begin{array}{l}\text { Cytomegalovirus, EBV, RSV, } \\
\text { parainfluenza-3, paramyxovírus }\end{array}$ & & \\
\hline & $\begin{array}{l}\text { Nem tuberculoid mycobacteriu- } \\
\text { mok }\end{array}$ & $\begin{array}{l}\text { Nem tuberculoid mycobacteriu- } \\
\text { mok }\end{array}$ & \\
\hline & $\begin{array}{l}\text { Candida, Aspergillus, } \\
\text { Scedosporium, } \\
\text { Cryptococcus neoformans, } \\
\text { Histoplasma capsulatum }\end{array}$ & Candida, Aspergillus & \\
\hline
\end{tabular}

$\mathrm{EBV}=$ Epstein-Barr-vírus; PAD = primer antitesthiányos állapot; PID = primer immundeficientia; RSV = respiratoricus syncytialis vírus

légzőrendszerre vonatkozik [8]. Hangsúlyozni kell azonban, hogy e gyanújelek érzékenysége a különböző PID-kórképekben jelentősen eltér [9]. Az infekciók jellemzően súlyosak, perzisztensek, szokatlan kórokozók okozzák, és visszatérőek. A különböző betegcsoportokban recidív sinusitis 19-98\%-ban, pneumonia 37-90\%ban volt prezentációs jele az antitesthiányos betegségnek [10]. Az Európai Immundeficientia Társaság több mint 2200 CVID-betegének adatai alapján a pneumonia a vezetô légúti betegség [11].

A poliszacharidtok védelmet biztosít egyes baktériumok számára az alternatív komplementaktivációval és phagocytosissal szemben; e kórokozók eliminációjában az antitestek központi szerepet játszanak. Ezért a légzőrendszer fertőzéseit, a tüdőgyulladást antitesthiányos állapotban tipikusan tokos baktériumok, Streptococcus pneumoniae és Haemophilus influenzae, valamint Staphylococcus aureus okozzák (2. táblázat). Mivel a védôoltások után rendszerint nem alakul ki antitestválasz, az oltás ellenére Bordetella pertussis is lehet etiológiai tényező [2]. XLA-ban mycoplasma fordulhat elő nagyobb arányban [12]. A baktériumok mellett a légúti vírusok szintén gyakoriak, és elhúzódó fertózést okoznak, ezek szerepéről azonban kevesebb az adat. Egy téli időszakban végzett vizsgálatban, CVID-betegek légúti exacerbatiójában 56\%-ban izoláltak vírusokat, mindenekelőtt rhinovirust, corona- és adenovírust, és 33\%-ban igazolódott többnyire tokos baktérium (Haemophilus influenzae) [13].

A kombinált T-és B-sejt-immundefektusok (CID) a legsúlyosabb következményeket okozó PID-betegségek. A csoporton belül is elkülöníthető a súlyos CID (sCID), melyet igen kifejezett T-sejtszám-csökkenés vagy -hiány jellemez. A sCID hátterében 17 különböző génhiba ismert [1]. A sCID korán manifesztálódik, és immunológiai sürgősségi állapotot jelent. A T-sejt-defektus következménye az intracellularis patogének okozta fokozott fertőzéshajlam. Az infekciók invazívak, elhúzódóak. sCID-ben a légzőrendszeri fertőzések a leggyakoribbak, amelyeket fóként a Pneumocystis jirovecii, cytomegalovirus, adenovírus, parainfluenzavírus-3 és RSV okoz [14]. Mivel egyidejúleg B-sejt-hiány vagy -funkció-zavar is jelen van, az antitesthiányos betegségekre jellemző kórokozóspektrummal is számolni kell. Sokszor a P. jirovecii-pneumonia az első prezentációs jel, amely kezdetben diffúz interstitialis, majd gócos, asszimmetrikus alveolaris infiltratio képében jelenik meg [15]. A hagyományosan immundeficientiaszindrómákhoz sorolt hiper-IgEszindróma (HIES) szintén kombinált immundefektusnak számít, és a leggyakrabban a STAT3 mutációja okozza. HIES-ban a rekurráló sinopulmonalis fertőzések vezető kórokozója a Staphylococcus aureus. A STAT3-HIES-re különösen jellemző a bronchiectasia és a pneumatokele, amely hajlamos kolonizálódni a cystás fibrosisra tipikus patogénekkel, Pseudomonas és nem tuberculoid (korábbi nevén atípusos) mycobacteriumokkal, valamint Aspergillus- és Scedosporium-speciesekkel [16]. A hiper-IgMszindróma (HIGM) a B-sejtek izotípusváltásának defektusát okozó genetikai betegségeket foglalja magában. Jellegzetessége az alacsony IgG-, IgA-szint mellett normális vagy magas IgM-szint. Az esetek $70 \%$-ában a Bsejtek T-sejt-függő kostimulációjáért felelős CD40L mutációja áll a háttérben [17], és mivel ez a ligand a phagocyták aktivációjában is szerepet játszik, a HIGM szintén a CID-ek közé tartozik. A PAD-ra jellemző kórokozók mellett a Pneumocystis jirovecii okozhat légúti fertőzést. A HIGM egyéb típusaiban az izotípusváltás hibája többnyire B-sejt-függő, és ezért - a jellegzetes lymphoid hyperplasiától eltekintve - a primer antitestdefektusok klinikai következményeivel járnak [18].

A phagocyták veleszületett zavarai lehetnek számbeliek (congenitalis neutropeniák) és/vagy funkcionálisak (leukocytaadhaesiós defektusok, krónikus granulomatosis [CGD]). CGD-ben a NADPH-oxidáz enzimkomplex mutációi miatt a reaktívoxigén-gyökök képzésének és a fagocitált kórokozók eliminációjának következményes zavara áll fenn. A leggyakrabban izolált légúti patogének a Staphylococcus aureus, a Burkholderia cepacia, a Klebsi- 
ella, a Nocardia, valamint az Aspergillus [19]. Az antifungális profilaxis ellenére a légúti gombafertőzések (mindenekelőtt Aspergillus) a vezető halálok. Congenitalis neutropeniában Staphylococcusok, Streptococcusok, Enterococcusok, Pseudomonas aeruginosa és Gram-negatív bacillusok a bőr- és lágyrész-fertőzések mellett az alsó és felső légúti infekciók okai [20].

A komplementrendszer korai komponenseinek defektusai $(\mathrm{Cl}-4)$ a tokos baktériumok okozta fertőzésekre hajlamosítanak; különösen a C3-defektusra jellemző a korai kezdetü, invazív és visszatérő, Streptococcus pneumoniae okozta infekció. A terminális komplex defektusaiban $\mathrm{Ne}$ isseria-fertőzésekkel kell számolni.

\section{Nem fertőzéses tüdőmanifesztációk}

Primer immundefektusokban a nem közvetlenül patogének által okozott krónikus tüdőelváltozásoknak az obstruktív vagy restriktív kórélettani jellemzőik alapján történő felosztása az eltérő etiológia miatt is indokoltnak tûnik.

\section{Obstruktív tüdőbetegségek}

A krónikus vagy recidív alsó légúti fertőzések szövődménye a bronchiectasia. A gyulladásos folyamat a hörgók falát és a környező szöveteket károsítja; előrehaladott állapotban a hörgő orsó- vagy zsákszerüen irreverzibilisen kitágul, majd hegesedik. A kórfolyamat kezdetén köbhámsejtek foglalják el a károsodott cilium helyét, amit a hörgőfal elasztikus szövetének pusztulása, a parenchyma sejtes beszűrődése, ödémája, végül az izomréteg és a porc destrukciója követ, endarteritis kíséretében. A lumen gyakran mucopurulens váladékkal és szövettörmelékkel kitöltött [21]. A kialakult bronchiectasia talaján, a cystás fibrosishoz hasonlóan, krónikusan kolonizáló Pseudomonas aeruginosa, Staphylococcus aureus és a nem tuberculoid mycobacteriumok lesznek a domináns patogének, ami önmagát fenntartó és súlyosbító folyamatot idéz elő [22]. A bronchiectasia kifejlődésének egyik leggyakoribb oka bármely, a tüdő visszatérő gennyes fertőzésére hajlamosító primer immundefektus. Ebbe a csoportba tartoznak az elsődleges antitesthiányos állapotok (agammaglobulinaemiák, CVID), egyes kombinált immundefektusok (STAT5b-deficientia, PI3KD-szindróma) és a phagocytadefektusok. Az elsődlegesen antitesthiányos betegségek enyhébb formáiban (IgG-alosztálydeficientia vagy szelektív IgA-hiány) a bronchiectasia incidenciája alacsonyabb. Az agammaglobulinaemia különösen hajlamosít hörgótágulatra, azonban a korai kezdetű sinopulmonalis fertőzések korábbi diagnózist és az immunglobulinpótló kezelés mihamarabbi elkezdését teszik lehetővé, ezért ebben a betegcsoportban a kialakulása ritkább, mint CVID-ben [23]. A különböző vizsgálatokban a bronchiectasia prevalenciája antitesthiányos betegségekben 17-76\% volt [10]. Az ESID-regiszter adatai szerint CVID-ben bronchiectasia 23\%-ban fordult elő, és sokszor már a kórkép felismerésekor jelen van bronchiectasia. Ennek magyarázata lehet, hogy a CVID kórismézése átlagosan 4,1 évet késik, gyermekkorban (<10 év) hosszabb idő telt el a betegség kezdete és a diagnózis felállítása között. A bronchiectasiával érintett betegek IgM-szintje alacsonyabb, ami az IgM protektív szerepére utal [11].

Krónikus légúti tünetek esetén vagy a rizikócsoportba tartozó betegeknél rendszeresen, szűrőjelleggel nagy felbontású CT (HRCT) elvégzése javasolt. A korai elváltozások kimutatására a röntgen nem alkalmas. A bronchiectasia tipikus CT-jelei a hörgők falának megvastagodása, hörgőtágulatok, a kaliber csökkenésének hiánya. Elsősorban a középső és az alsó lebenyek érintettek [15, 24]. A kis légutak érintettségének korai kimutatására hasznos módszer a ki- és belégzési HRCT-felvételek összevetése. A légzésfunkciós vizsgálat obstruktív mintázatot mutat (alacsony forszírozott kilégzési térfogat $1 \mathrm{~s}$ alatt $\left[\mathrm{FEV}_{1}\right]$, alacsony vagy normál $\mathrm{FEV}_{1}$ /eróltetett vitálkapacitás [FVC] hányados), súlyos tüdőkárosodásban az FVC is beszúkül. A légzésfunkciós vizsgálat a beteg megfelelő együttműködését igényli, ezért a vizsgálat gyermekkorban általában iskoláskortól végezhető el. A korai szakaszban elkezdett adekvát és agresszív terápia kedvező prognózist jelent. Egyes megfigyelések szerint gyermekkorban a bronchiectasia megfelelö kezelés mellett nem feltétlenül progresszív szövődmény [25].

\section{Restriktív tüdőbetegségek}

Egyes PID-kórképek fö szövődménye az interstitialis tüdőbetegség (interstitial lung disease, ILD), amely megnövekedett mortalitással és a malignus lymphoproliferativ betegségek fokozott kockázatával jár együtt. Az ILD patológiai jellemzóje az alveolaris fal gyulladásos megvastagodása, károsodása, a tüdő interstitiumának sejtes beszűrődése, majd fibrosisa és az alveolocapillaris egység destrukciója, ami a légzőfelület beszúkülésével restriktív tüdőbetegséget okoz. Mivel a folyamat nem csak az interstitiumra korlátozódik, valójában helyesebb diffúz parenchymás tüdőbetegségról beszélni [26]. Az ILD a késői stádiumban okoz tüneteket, gyermekkori megjelenése ritka. A klinikum lappangó, kezdetben fáradékonyság, a fizikai teljesítmény csökkenése, majd improduktív köhögés, zihálás, tachypnoe és nyugalmi dyspnoe jelentkezik. Belégzésben az érintett területeken apró hólyagú, nedves szörtyzörejek hallhatók. Előrehaladott esetben pulmonalis hypertonia, cor pulmonale chronicum és légzési elégtelenség alakul ki.

Az ILD krónikus gyulladásos folyamatok szövettanilag heterogén csoportját, elsősorban a szokványos és lymphocytás interstitialis pneumonitist, a follicularis bronchiolitist, a granulomatosus tüdőbetegséget és a szervülő pneumoniát foglalja magában [26]. Miközben a légutak szerkezeti károsodása a visszatérô fertőzések kumulatív hatásának következtében, a tüdőszövet hegesedése miatt alakul ki, az ILD patogeneziséért elsősorban az immun- 
diszreguláció felelős [27]. A parenchymás tüdőbetegség kialakulásához, bár gyakran egyidejûleg jelen van, nem szükséges a bronchiectasia, és jellemzőbb az emelkedett, mint a csökkent szérum-IgM-szint [28]. Az interstitialis tüdőbetegség kockázatával elsődlegesen antitesthiányos állapotokban és egyes specifikus (ataxia teleangiectasia, CGD), illetve szisztémás autoimmun betegségekkel aszszociált PID-kórképekben kell számolni (3. táblázat) [3, 29, 32]. ILD az elsődlegesen antitesthiányos betegségek (PAD) közül, az alábbiakban részletezett CVID-en kívül, az IgG-alosztály-deficientiában gyakoribb; a leggyakoribb PID-kórképben, a szelektív IgA-deficientiában társult IgG2-alosztály-hiány esetén fordul elő [28, 29].

$\mathrm{Az}$ interstitialis tüdőbetegségek specifikus és egyben leggyakoribb típusa a granulomatosus-lymphocytás ILD (GLILD), mely szövettanilag granulomatosis és lymphoid hyperplasia (follicularis bronchiolitis, nodularis lymphoid hyperplasia, reactiv lymphoid infiltratio és lymphocytás interstitialis pneumonia) kombinációjaként jelenik meg. GLILD gyakran társul autoimmun cytopeniával, lymphadenopathiával, spleno- és hepatomegaliával, valamint egyéb extrapulmonalis, nem elsajtosodó granulomaképzéssel, és lényegében a szisztémás granulomatosus folyamat tüdőmanifesztációjának tekinthető. Granulomatosus-lymphocytás ILD-t HIGM- vagy XLAbetegeknél nem írtak le, ebből arra következtetnek, hogy immunregulációs zavart okozó T-sejt-diszfunkció a fó patogenetikai tényező [18, 22]. Az immunregulációs zavar mellett egyes vizsgálatok a humán herpeszvírus-8 és az Epstein-Barr-vírus kóroki szerepét is felvetették [33, 34], ezt azonban a késóbbi vizsgálatok nem erősítették meg. A GLILD elsődlegesen CVID-ben fordul elő. Szakértői konszenzuson alapuló definíció szerint a GLILD a CVID-betegek klinikailag, radiológiailag és szövettanilag specifikus, a tüdő lymphocytás beszűrődésével és/ vagy granulomatosisával asszociált interstitialis tüdőbetegsége, ahol az egyéb etiológia kizárható [35]. A GLILD prevalenciája CVID-páciensek körében nem ismert pontosan, a különböző betegcsoportokban 5-20\%, de az előfordulási gyakoriság feltehetően ennél magasabb [28]. Gyakran a CVID diagnózisának felállításakor, viszonylag korán jelen van parenchymás tüdőbetegség, ezért úgy tünik, hogy a CVID-betegek egy alcsoportja különösen hajlamos erre a szövődményre. A fokozott ILD-rizikónak kitett CVID-betegcsoport azonosításában az emelkedett CD4/CD8 arány, a magas IgM-szint és a nagyon alacsony osztályváltott memória-B-sejt-érték hasznos markerekként szolgálhatnak [30]. Az érintett betegekben alacsony a keringő regulatorikus T-sejtek aránya, és a tüdőből nyert szövettani mintában ez a sejttípus nem mutatható ki [3]. Granulomatosus interstitialis tüdőbetegség előfordulhat egyéb, ritkább monogénes PID-kórképekben is, amelyek diagnózisa genetikai vizs-

3. táblázat | Interstitialis tüdőbetegséggel asszociált PID-kórképek ([3, 29-32] alapján)

\begin{tabular}{|c|c|c|}
\hline PID & ILD-patológia & HRCT-lelet \\
\hline \multicolumn{3}{|l|}{$\begin{array}{l}\text { Elsődlegesen antitesthiányos } \\
\text { állapotok (PAD) }\end{array}$} \\
\hline - Ig-alosztály-deficientia & $\begin{array}{l}\text { Lymphocytás interstitialis pneumonia, } \\
\text { szokványos interstitialis pneumonitis, } \\
\text { bronchiolitis obliterans szervülö pneumoniá- } \\
\text { val }\end{array}$ & $\begin{array}{l}\text { Basalis és perifériás reticularis homály, trakciós } \\
\text { bronchiectasia, subpleuralis lépesmézszerű } \\
\text { szerkezet }\end{array}$ \\
\hline - CVID és egyéb CVID-fenotípus (TACI) & $\begin{array}{l}\text { Bronchiolitis obliterans szervülő pneumoniá- } \\
\text { val, allergiás pneumonitis, GLILD: granulo- } \\
\text { matosis és lymphoid hyperplasia (follicularis } \\
\text { bronchiolitis, nodularis lymphoid hyperplasia, } \\
\text { lymphocytás interstitialis pneumonia) }\end{array}$ & $\begin{array}{l}\text { Elsősorban az alsó tüdőmezők érintettek: } \\
\text { beszűrődés, } \\
\text { centrilobularis nodularis rajzolat, } \\
\text { tejüvegszerű homály } \\
\text { lépesmézszerű szerkezet }\end{array}$ \\
\hline \multicolumn{3}{|l|}{ PID-szindrómák } \\
\hline - Ataxia teleangiectasia & Lymphocytás beszürődés, fibrosis & $\begin{array}{l}\text { Az alsó tüdőmezők diffúz beszűrődése, az } \\
\text { interlobularis septum megvastagodása }\end{array}$ \\
\hline - Krónikus granulomatosis & $\begin{array}{l}\text { Homogén microgranulomák, óriássejtes és } \\
\text { lymphocytás infiltratióval }\end{array}$ & $\begin{array}{l}\text { Alsó tüdőmezók, centrolobularis nodulusok, } \\
\text { tejüvegszerú homály }\end{array}$ \\
\hline \multicolumn{3}{|l|}{ Immundiszregulációval járó PID } \\
\hline - CTLA4 & Lásd CVID & Lásd CVID \\
\hline \multicolumn{3}{|l|}{ - LRBA-deficientia } \\
\hline \multicolumn{3}{|l|}{ - STAT3 funkciónyerő mutáció } \\
\hline - XIAP-deficientia & & \\
\hline
\end{tabular}

CTLA-4 = cytotoxicus T-lymphocytaantigén-4; CVID = variábilis immunhiány; GLILD = granulomatosus-lymphocytás interstitialis tüdőbetegség; HRCT = nagy felbontású komputertomográfia; ILD = interstitialis tüdőbetegség; LRBA = lipopoliszacharidra reagáló bézsszerű horgony; PID = primer immundeficientia; STAT3 = jelátvivő és transzkripciós aktivátor-3; TACI = transzmembránaktiváló és kalciummodulátor ciklofilinligand-közremúködő; XIAP = X-hez kötött apoptózisgátló 
gálatot, célzott vagy új generációs szekvenálási technológiát igényel.

Az elkülönítő kórisme a fertőzéseket, a szervülő pneumoniát, az egyéb etiológiájú lymphocytás pneumoniát, a sarcoidosist és a lymphomát foglalja magában. A sarcoidosistól való differenciálás nehézséget okozhat, különösen, ha a CVID nem ismert. Ilyenkor segítséget jelent a fokozott fertőzéshajlam, a hypogammaglobulinaemia, a csökkent osztályváltott memória-B-sejt-érték, az esetleges autoimmun cytopenia, a máj nodularis regeneratív hyperplasiája. Ellentétben a GLILD-del, sarcoidosisra radiológiailag elsősorban a felső tüdőmezők micronodularis rajzolata, a kifejezett hilaris adenopathia jellemző, és általában nincs bronchiectasia $[3,36]$.

Az ILD lehet tünetmentes, ezért a fokozott kockázatú betegek szürése indokolt. Interstitialis tüdőbetegség gyanúja esetén javasolt protokoll a HRCT-vizsgálatot, légzésfunkciós vizsgálatokat, a fertőzés kizárására bronchoszkópiát és a szövettani vizsgálatot foglalja magában [35]. A jellegzetes eltérések korai felismerésére egyértelmúen a HRCT javasolt, a röntgenvizsgálat nem eléggé szenzitív. ILD-re a hisztológiai beosztásnak megfelelő változatos radiológiai eltérések láthatók. GLILDre tipikus az alsó tüdőmezók érintettsége, a centrolobularis reticulonodularis rajzolatfokozódás, tejüvegszerü homály, lépesmézszerű tüdőszerkezet és a mediastinalis lymphadenopathia. A légzésfunkciós vizsgálat restriktív tüdőbetegségre jellemző paramétereket, csökkent FVC-t és/vagy csökkent CO-diffúziós kapacitást mutat, azonban gyakran van jelen egyidejü obstruktív mintázat (csökkent $\mathrm{FEV}_{1}$, normál vagy emelkedett $\mathrm{FEV}_{1} / \mathrm{FVC}$ aránnyal). A CO diffúziós kapacitásának mérése az egyik legmegbízhatóbb diagnosztikai módszer ILD-ben, csökkenése megelőzheti az FVC beszúkülését, és ezért már korai fázisban igazolhatja a parenchymás tüdőbetegséget. A módszer ugyanakkor nagyfokú együttmúködést igényel, ami a gyermekkori alkalmazhatóságot nagymértékben korlátozza. A diagnózis felállításához citológiai vizsgálatra van szükség, mely történhet bronchoalveolaris mosással (BAL) vagy biopsziával nyert mintából. A BAL elsősorban a fertőzések és az elkülönítő kórisme szempontjából lényeges betegségek, például sarcoidosis, Langerhans-histiocytosis, hypersensitiv pneumonia vagy alveolaris proteinosis kimutatásában tûnik hasznosnak [37]. Amennyiben a klinikai kép, a képalkotó vizsgálatok és a BAL együttes értékelésével sem állítható fel egyértelmú diagnózis, vagy az eredmények ellentmondásosak, szövettani vizsgálat indokolt. Szövettani mintavételre sor kerülhet a hörgőtükrözés során is, azonban CVID-ben a GLILD diagnózisának felállításához a sebészeti beavatkozással történő mintavételt részesítik előnyben [35]. A bioptátumból CD3, CD4, CD8 és CD20 sejtfelszíni markerek immunhisztokémiai kimutatása, baktérium(Mycoplasma is) és gombaspecifikus festés, valamint lymphoma kizárására klonalitásvizsgálat javasolt [35].

\section{A légzőrendszer egyéb betegségei}

Egyes primer antitestdefektusokban (szelektív IgA-hiány, CVID) gyakoribb az allergiás betegségek, köztük az asztma előfordulása.

A PID-betegek második vezető mortalitási tényezőjét a rosszindulatú betegségek jelentik. A CVID vagy egyéb PID-betegségek vonatkozásában a pulmonalis lymphoma, elsősorban a non-Hodgkin-lymphoma a tüdőt érintő leggyakoribb malignus szövődmény [38, 39], a szolid tumorok ritkák. Előfordulhat egyes benignus lymphoproliferatiók (például lymphocytás interstitialis pneumonia) rosszindulatú elfajulása.

A pulmonalis alveolaris proteinosist a surfactanteredetû fehérjék akkumulációja okozza, amelynek hátterében az alveolaris macrophagok phagocytadefektusa áll. Lehet szerzett (GM-CSF elleni antitestek jelenléte miatt) vagy veleszületett, ez utóbbi esetben a GM-CSF receptorának egyik alegységét (CSF2RA) kódoló génhiba az etiológia [40]. Az érintett betegek fogékonyak az opportunista fertőzésekkel szemben.

Anyagi támogatás: A kézirat megírása anyagi támogatásban nem részesült.

A szerző a cikk végleges változatát elolvasta és jóváhagyta.

Érdekeltségek: A szerzőnek nincs érdekeltsége.

\section{Irodalom}

[1] Picard C, Al-Herz W, Bousfiha A, et al. Primary immunodeficiency diseases: an update on the classification from the International Union of Immunological Societies Expert Committee for Primary Immunodeficiency 2015. J Clin Immunol. 2015; 35 : 696-726.

[2] Jesenak M, Banovcin P, Jesenakova B, et al. Pulmonary manifestations of primary immunodeficiency disorders in children. Front Pediatr. 2014; 2: 77

[3] Baumann U, Routes JM, Soler-Palacín P, et al. The lung in primary immunodeficiencies: new concepts in infection and inflammation. Front Immunol. 2018; 9: 1837.

[4] Vetrie D, Vorechovský I, Sideras P, et al. The gene involved in $\mathrm{X}$-linked agammaglobulinaemia is a member of the $\operatorname{src}$ family of protein-tyrosine kinases. Nature 1993; 361: 226-233.

[5] Chapel H, Cunningham-Rundles C. Update in understanding common variable immunodeficiency disorders (CVIDs) and the management of patients with these conditions. Br J Haematol. 2009; 145: 709-727.

[6] Cunningham-Rundles C, Maglione PJ. Common variable immunodeficiency. J Allergy Clin Immunol. 2012; 129: 14251426.

[7] Lawrence MG, Palacios-Kibler TV, Workman LJ, et al. Low serum $\operatorname{IgE}$ is a sensitive and specific marker for common variable immunodeficiency (CVID). J Clin Immunol. 2018; 38: 225233.

[8] Jeffrey Modell Foundation. 10 warning signs of primary immunodeficiency for adults, 2009. Available from: http://www.info4pi.org/library/educational-materials/10-warning-signs [accessed: July 23, 2018]. 
[9] O'Sullivan MD, Cant AJ. The 10 warning signs: a time for a change? Curr Opin Allergy Clin Immunol. 2012; 12: 588-594.

[10] Wood P, Stanworth S, Burton J, et al., UK Primary Immunodeficiency Network. Recognition, clinical diagnosis and management of patients with primary antibody deficiencies: a systematic review. Clin Exp Immunol. 2007; 149: 410-423.

[11] Gathmann B, Mahlaoui N, Gérard L, et al., European Society for Immunodeficiencies Registry Working Party. Clinical picture and treatment of 2212 patients with common variable immunodeficiency. J Allergy Clin Immunol. 2014; 134: 116-126.

[12] Roberts D, Murray AE, Pratt BC, et al. Mycoplasma hominis as a respiratory pathogen in $\mathrm{X}$-linked hypogammaglobulinaemia. J Infect. 1989; 18: 175-177.

[13] Sperlich JM, Grimbacher B, Workman S, et al. Respiratory infections and antibiotic usage in common variable immunodeficiency. J Allergy Clin Immunol Pract. 2018; 6: 159-168.e3.

[14] Notarangelo LD. Primary immunodeficiencies. J Allergy Clin Immunol. 2010; 125: 182-194.

[15] Jeanes AC, Owens CM. Chest imaging in the immunocompromised child. Paediatr Respir Rev. 2002; 3: 59-69.

[16] Sowerwine KJ, Holland SM, Freeman AF. Hyper-IgE syndrome update. Ann N Y Acad Sci. 2012; 1250: 25-32.

[17] Allen RC, Armitage RJ, Conley ME, et al. CD40 ligand gene defects responsible for X-linked hyper-IgM syndrome. Science 1993; 259: 990-993.

[18] Winkelstein JA, Marino MC, Ochs H, et al. The X-linked hyperIgM syndrome: clinical and immunologic features of 79 patients. Medicine (Baltimore) 2003; 82: 373-384.

[19] Roos D. Chronic granulomatous disease. Br Med Bull. 2016; 118: 50-63.

[20] Donadieu J, Beaupain B, Fenneteau O, et al. Congenital neutropenia in the era of genomics: classification, diagnosis, and natural history. Br J Haematol. 2017; 179: 557-574.

[21] Nagy B. Bacterial pneumonia. In: Cserháti E, Gyurkovits K, Nagy B. (eds.) Diseases of respiratory tract in childhood. [Bakteriális pneumonia. In: Cserháti E, Gyurkovits K, Nagy B. (szerk.) Gyermekkori légzőszervi megbetegedések]. Medicina Könyvkiadó, Budapest, 2003; pp. 176-184. [Hungarian]

[22] Notarangelo LD, Plebani A, Mazzolari E, et al. Genetic causes of bronchiectasis: primary immune deficiencies and the lung. Respiration 2007; 74: 264-275.

[23] Aghamohammadi A, Allahverdi A, Abolhassani H, et al. Comparison of pulmonary diseases in common variable immunodeficiency and X-linked agammaglobulinaemia. Respirology 2010; 15: 289-295.

[24] Bierry G, Boileau J, Barnig C, et al. Thoracic manifestations of primary humoral immunodeficiency: a comprehensive review. Radiographics 2009; 29: 1909-1920.

[25] Haidopoulou K, Calder A, Jones A, et al. Bronchiectasis secondary to primary immunodeficiency in children: longitudinal changes in structure and function. Pediatr Pulmonol. 2009; 44: 669-675.

[26] Nagy B. Diffuse parenchymal (interstitial) lung diseases. In: Cserháti E, Gyurkovits K, Nagy B. (eds.) Diseases of respiratory tract in childhood. [Diffúz parenchymás (interstitialis) tüdőbetegségek. In: Cserháti E, Gyurkovits K, Nagy B. (szerk.) Gyer- mekkori légzőszervi megbetegedések.] Medicina Könyvkiadó, Budapest, 2003; pp. 281-284. [Hungarian]

[27] van de Ven AA, de Jong PA, Hoytema van Konijnenburg DP, et al. Airway and interstitial lung disease are distinct entities in paediatric common variable immunodeficiency. Clin Exp Immunol. $2011 ; 165: 235-242$.

[28] Schussler E, Beasley MB, Maglione PJ. Lung disease in primary antibody deficiencies. J Allergy Clin Immunol Pract. 2016; 4: 1039-1052.

[29] Popa V, Colby TV, Reich SB. Pulmonary interstitial disease in Ig deficiency. Chest 2002; 122: 1594-1603.

[30] Maglione PJ, Overbey JR, Radigan L, et al. Pulmonary radiologic findings in common variable immunodeficiency: clinical and immunological correlations. Ann Allergy Asthma Immunol. 2014; 113: 452-459.

[31] Schroeder SA, Swift M, Sandoval C, et al. Interstitial lung disease inpatients with ataxia-telangiectasia. Pediatr Pulmonol. 2005; 39: $537-543$

[32] Kawai T, Watanabe N, Yokoyama M, et al. Interstitial lung disease with multiple microgranulomas in chronic granulomatous disease. J Clin Immunol. 2014; 34: 933-940.

[33] Wheat WH, Cool CD, Morimoto Y, et al. Possible role of human herpesvirus 8 in the lymphoproliferative disorders in common variable immunodeficiency. J Exp Med. 2005; 202: 79-84.

[34] Stewart JP, Egan JJ, Ross AJ, et al. The detection of Epstein-Barr virus DNA in lung tissue from patients with idiopathic pulmonary fibrosis. Am J Respir Crit Care Med. 1999; 159: 13361341.

[35] Hurst JR, Verma N, Lowe D, et al. British Lung Foundation/ United Kingdom Primary Immunodeficiency Network consensus statement on the definition, diagnosis, and management of granulomatous-lymphocytic interstitial lung disease in common variable immunodeficiency disorders. J Allergy Clin Immunol Pract. 2017; 5: 938-945.

[36] Verbsky JW, Routes JM. Sarcoidosis and common variable immunodeficiency: similarities and differences. Semin Respir Crit Care Med. 2014; 35: 330-335.

[37] Gharsalli H, Mlika M, Sahnoun I, et al. The utility of bronchoalveolar lavage in the evaluation of interstitial lung diseases: a clinicopathological perspective. Semin Diagn Pathol. 2018 Aug 24. pii: S0740-2570(18)30051-0. doi: 10.1053/j.semdp.2018.08. 003. [Epub ahead of print]

[38] Bal A, Gupta A, Sodhi KS, et al. Multifocal extranodal nonHodgkin lymphoma involving both the lungs and brain in a child with primary immunodeficiency. J Pediatr Hematol Oncol. 2008; 30: 317-319.

[39] Cunningham-Rundles C, Lieberman P, Hellman G, et al. NonHodgkin lymphoma in common variable immunodeficiency. Am J Hematol. 1991; 37: 69-74.

[40] Suzuki T, Sakagami T, Rubin BK, et al. Familial pulmonary alveolar proteinosis caused by mutations in CSF2RA. J Exp Med. 2008; 205: 2703-2710.

(Nyul Zoltán dr.

Pécs, József Attila u. 7., 7623 e-mail: nyul.zoltan@pte.hu) 